\title{
Socio-economic Status, Sheep Husbandry Practices and Morphological Patterns of Macherla Sheep, a Lesser-known Sheep Breed of Andhra Pradesh
}

\author{
P. Panduranga Reddy ${ }^{1 *}$, R. Vinoo ${ }^{1}$, M. Muralidhar ${ }^{1}$, Ch. Venkatasesaiah ${ }^{2}$, \\ K. Aswani Kumar ${ }^{3}$ and K. Sudhakar ${ }^{1}$ \\ ${ }^{1}$ Department of AGB, NTR College of Veterinary Science, Gannavaram, Andhra Pradesh, INDIA \\ ${ }^{2}$ Livestock Farm Complex, NTR College of Veterinary Science, Gannavaram, Andhra Pradesh, INDIA \\ ${ }^{3}$ Department of Veterinary Biochemistry, NTR College of Veterinary Science, Gannavaram, Andhra Pradesh, INDIA \\ *Corresponding author: PR Punuru; E-mail: panduvet@gmail.com
}

Received: 20 Aug., 2020

Revised: 13 Sept., 2020

Accepted: 16 Sept., 2020

\begin{abstract}
A study on socio-economic status of Macherla sheep rearing farmers, sheep husbandry practices, and morphological patterns of Macherla sheep was carried out on 92 shepherds and 1279 sheep in Guntur, Prakasam, and Krishna districts of Andhra Pradesh and Nagar Kurnool district of Telangana state. The study revealed that $79.34 \%$ and $20.65 \%$ of the farmers had primary and secondary school education respectively with an average of 5.44 members per family. Most of the sheep houses were of open type (61\%) with kutcha type of floors $(80.43 \%)$. The average land holding capacity was 3.41 acres and the mean annual income of the shepherds was ₹ 1,01,043 with a range of ₹ 75,000 to 2,00,000 and the mean flock size was $134.31 \pm 4.60$. The most common practice of feeding was grazing $(70.58 \%)$. Major breeding season was July to September, while the minor breeding season was March to May. All the farmers in the study area immunized their sheep to protect them from infectious diseases and $79.41 \%$ of them followed a periodical deworming schedule. In most of the flocks, mortality of adult sheep was below 5\% and in lambs $11-20 \%$. The predominant color pattern was bi-colour of white and black (44.41\%) followed by brown and white $(35.65 \%)$, exclusive brown (18.64\%), and exclusive black (1.88\%). The most common head profile was convex (84.91\%), majority of animals had pendulous ear pattern $(96.79 \%)$ and $75.45 \%$ animals had wattles. Both sexes are horned and oriented backward, downward and forward. Further, $84.55 \%$ animals had slender type tail.
\end{abstract}

\section{HIGHLIGHTS}

(0 About $75 \%$ of farmers followed both migratory and stationary type of sheep rearing.

( White and black was the predominant color pattern followed by brown and white (35.65\%), and brown (18.64\%), and black $(1.88 \%)$.

(0 The predominant head profile was convex (84.91\%) and ears pattern was mostly pendulous.

Keywords: Sheep Husbandry Practices, Socio-economic status, housing, feeding, Andhra Pradesh, Telangana

Sheep, a typical small ruminant is an important species of livestock in India. Sheep rearing plays an important role in the source of livelihood and employment for millions of rural households, especially in regions with uneconomical crop and dairy farming. The prevalence of unscientific managemental practices, marketing vulnerabilities, societal facets and economic aspects of shepherds were the reasons for poor performance of sheep in India. At present, the high-income elasticity of demand for sheep products is on constant rise because of the increased consumer's percapita income, diet consciousness and rapid urbanization. Rising demand for mutton coupled with low capital investment and recurring cost, quick

How to cite this article: Reddy, P.P., Vinoo, R., Muralidhar, M. Venkatasesaiah, Ch. K., Kumar, A. and Sudhakar, K. (2020). Socioeconomic status, sheep husbandry practices and morphological patterns of Macherla sheep, a lesser-known sheep breed of Andhra Pradesh. J. Anim. Res., 10(5): 827-835.

Source of Support: None; Conflict of Interest: None 
return and less risk make sheep farming as a profitable and sustainable enterprise to different categories of rural households.

Sheep plays an important role in economy of Andhra Pradesh with second highest population (17.6 million) in the country (BAHS, 2019). The state is blessed with high productive sheep breeds like Nellore. The superior performance of Nellore sheep is well studied (Kumari et al., 2013). Macherla sheep breed is a lesser known breed of Andhra Pradesh with higher productive and reproductive potentials than Nellore sheep. Further, the breeding tract of Macherla sheep has high temperature and humidity and the sheep thrives well in harsh climatic conditions. However, promoting the Macherla sheep as a new breed is under emphasized due to lack of extensive studies on both genotypic and phenotypic characteristics. Hence, as a pilot project, the present study was carried out with an objective of documenting the morphological patterns of Macherla sheep and socio-economic profile of the Macherla sheep farmers along with husbandry practices, the type and structure of the sheep flocks.

\section{MATERIALS AND METHODS}

The study was conducted to characterize the lesser known Macherla sheep of Andhra Pradesh in Guntur, Krishna, and Prakasam districts of Andhra Pradesh and Nagar Kurnool district of Telangana (Fig. 1). The data pertaining to 341 flocks were collected from 92 shepherds. The questionnaire include husbandry practices, literacy level, annual income, family size, migratory practices, ownership status, land holding and type of land of the shepherds. Further, morphological features of Macherla sheep were studied from a total of 1279 sheep (61 rams, 692 ewes and 526 lambs).

\section{STATISTICAL ANALYSIS}

The data collected were scrutinized, collated and analyzed by the conventional tabular analysis in the form of mean, standard error and percentage using the methods suggested by Snedecor and Cochran (1994).

\section{RESULTS AND DISCUSSION}

\section{Flock management}

The average flock size of Macherla sheep in the present study is $134.31 \pm 4.6$ and the minimum flock size of the genetic group observed in the present study is 50 . In general, Macherla sheep are reared in larger flocks by the shepherds. Similar observation was noted by Choudary (2013) with an average flock size of 122.64. The flock sizes reported in Madras red sheep was 85 (9-315) (Raman et al., 2003), in North coastal sheep of Andhra Pradesh was 64.98 by Gangaraju (2010) and 67.46 by Anandarao (2010), Nellore jodipi was ranged from 25 to 30 (Virojirao et al., 2008). The overall income is directly depending on the flock size of the sheep farmers. The increase or decrease of the flock size is controlled by the factors such as number of family members, disease, grazing resources and availability of labour etc.

The study on migration practices showed that $75 \%$ of farmers followed both migratory and stationary type of sheep rearing and $17 \%$ farmers adopted stationary system alone while $8 \%$ of the farmers followed migratory type throughout the year. The average distance travelled by migratory flocks was $76.26 \mathrm{Km}$.

\section{Housing}

Macherla sheep were housed mostly during nights and the lambs were housed in special enclosure, which were similar to housing practices reported for North coastal sheep of Andhra Pradesh (Gangaraju, 2010; Anandarao, $2010)$. The nature of houses varied from part of residence $(66 \%)$ to separate house $(31 \%)$. Open housing system was observed in $61 \%$, while closed housing system was followed by $39 \%$ of the farmers. The shelter is more of Kutcha type (80.43\%) rather Puccatype, limiting the latter housing system to $15 \%$. Majority $(67 \%)$ of the shelters were made with thatched roof while 25 percent used asbestos and two percent of the houses had tiled roof. About six percent of houses had other roofing material such as bamboo and wooden material etc. The thatched roofs were mostly made of palmyra leaves.

\section{Feeding}

The feeding patterns followed by the shepherds are presented in Table 1. The most common practice of feeding was grazing $(70.58 \%)$ in the fields. Grazing and supplementation with grains (rice, jower, horse gram, and maize), especially for breeding rams and ram lambs was 
Table 1: The feeding pattern of Macherla sheep $(n=92)$

\begin{tabular}{|c|c|c|c|c|}
\hline Sl. No. & Feeding & Category & $\mathbf{n}$ & $\%$ \\
\hline \multirow{3}{*}{1} & \multirow{3}{*}{ Feeding practice adopted } & Grazing & 65 & 70.58 \\
\hline & & Stall feeding & 0 & - \\
\hline & & Grazing \&supplementation & 27 & 29.41 \\
\hline \multirow{3}{*}{2} & \multirow{3}{*}{ Form of supplementation } & Green fodder & 50 & 54.37 \\
\hline & & Dry fodder & 233 & 25 \\
\hline & & Concentrates & 19 & 20.63 \\
\hline \multirow{2}{*}{3} & \multirow{3}{*}{ Grazing time per day } & $6-8 \mathrm{hr}$ & 34 & 37.25 \\
\hline & & More than $8 \mathrm{hr}$ & 58 & $62 . .74$ \\
\hline \multirow{4}{*}{4} & & Community lands & 20 & 21.56 \\
\hline & \multirow{3}{*}{ Type of grazing lands available } & Forests & 5 & 5.88 \\
\hline & & Waste lands & 11 & 11.76 \\
\hline & & All & 56 & 60.78 \\
\hline \multirow{3}{*}{5} & \multirow{3}{*}{ Source of fodder for supplementation } & Homegrown & 40 & 43.13 \\
\hline & & Purchased & 52 & 56.86 \\
\hline & & Collected from fields & 0 & - \\
\hline \multirow{3}{*}{6} & \multirow{3}{*}{ Watering } & at housing & 2 & 1.96 \\
\hline & & at grazing & 39 & 42.15 \\
\hline & & Both & 51 & 55.88 \\
\hline \multirow{2}{*}{7} & \multirow{2}{*}{ Practice of Weaning } & Yes & 4 & 4 \\
\hline & & No & 88 & 96 \\
\hline
\end{tabular}

practiced by 29.42 percent farmers. The practice of grazing and supplementation is essential for maintaining good health and reproduction. The findings were in conformity with results of Gangaraju (2010) and Anandarao (2010) in Vizianagaram sheep. Feeding green fodder, dry fodder, concentrates at different proportions might be related to cropping pattern in the area and awareness about supplementary feeding among shepherds.

Majority of farmers practiced more than 8 hours of grazing (62.74\%) and 37.25 percent farmers adopted 6-8 hours grazing in fields. The tendency of walking longer distances in search of grazing material might be due to the exhaustion of locally available grazing lands. The present survey revealed that the migration period ranged between 5 months to 10-12 months in a year. During active crop time, Macherla sheep famers went for migration in to Nallamalla forest where Krishna river water can be utilized for drinking purpose both were present adjacent to the breeding tract. The forest was excellent source green fodder, abundance of green fodder may be one of the major reason for heavy size of the Macherla sheep and shepherds will stay 4 to 6 months in forest (September to February).

Majority of the shepherds informed that community lands, waste barren lands, roadside grass and harvested fields, forest lands were being utilized as grazing resources for sheep. The findings were similar to the results of Gangaraju (2010), Anandarao (2010) in Vizianagaram sheep. The extent of utilization of different grazing sources of the study area was well documented by Raju et al. (2018 and 2019). In the present study, it was observed that water was provided both during grazing and housing time. Providing water during grazing period is an important recommendation by researchers to ameliorate heat stress (Hyder et al., 2017a, b). Most of the farmers (96\%) have not adopted the important weaning management practice. Further, $20.63 \%$ of the shepherds fed their sheep with concentrate mixtue; majority of them included agroindustrial byproducts in concentrate mixture. Replacing conventional feed resources with agro-industrial byproducts such as non-protein nitrogen compounds is necessary to meet the feed resources' requirement for ever increasing population (Reddy et al., 2019a, b).

\section{Health management}

The health management practices of Macherla sheep are presented in Table 2. Majority of the shepherds dewormed their flocks thrice a year, while less proportion (20.58\%) performed deworming twice a year. All the farmers in 
西

Reddy et al.

Table 2: Health management practices followed for Macherla sheep

\begin{tabular}{|c|c|c|c|c|}
\hline Sl. No. & Health & Category & $\mathbf{n}$ & $\%$ \\
\hline \multirow{2}{*}{1} & \multirow{2}{*}{ Practice of Deworming $(\mathrm{n}=92)$} & Yes & 92 & 100 \\
\hline & & No & Nil & \\
\hline \multirow{3}{*}{2} & \multirow{3}{*}{ Control of ecto-parasites } & Yes & 69 & 75 \\
\hline & & No & 23 & 25 \\
\hline & & Once & Nil & \\
\hline \multirow[t]{2}{*}{3} & \multirow[t]{2}{*}{ Frequency of Deworming in a year } & Twice & 19 & 20.58 \\
\hline & & Thrice & 73 & 79.41 \\
\hline \multirow{2}{*}{4} & \multirow{2}{*}{ Vaccination done } & Yes & 92 & 100 \\
\hline & & No & Nil & \\
\hline \multirow{6}{*}{5} & \multirow{6}{*}{ Prevalence of diseases } & Blue Tongue & 64 & 62.74 \\
\hline & & Pestes Petites Ruminants & 72 & 70.58 \\
\hline & & Pneumonia & 61 & 59.80 \\
\hline & & Pox & 39 & 38.23 \\
\hline & & Enterotoxaemia & 8 & 7.84 \\
\hline & & Foot and Mouth & 6 & 5.88 \\
\hline \multirow{2}{*}{6} & \multirow{2}{*}{ Type of treatment } & Traditional & 22 & 24.04 \\
\hline & & Allopathy & 70 & 75.96 \\
\hline \multirow{3}{*}{7} & \multirow{3}{*}{ Disposal of sick animals } & By selling & 89 & 97.06 \\
\hline & & By self-consumption & 3 & 2.94 \\
\hline & & By selling & 11 & 11.76 \\
\hline \multirow[t]{3}{*}{9} & \multirow[t]{2}{*}{ Disposal of dead stock } & Throwing animals away from flocks & 71 & 77.45 \\
\hline & & By tying to trees & 10 & 10.78 \\
\hline & \multirow{8}{*}{ Information on mortality (\%) } & Among adult & & \\
\hline \multirow{7}{*}{10} & & $<5 \%$ & 47 & 50.98 \\
\hline & & $6-10 \%$ & 39 & 42.15 \\
\hline & & $>10 \%$ & 6 & 6.86 \\
\hline & & Among lambs & & \\
\hline & & $<10 \%$ & 20 & 21.56 \\
\hline & & $11-20 \%$ & 36 & 38.86 \\
\hline & & $>20 \%$ & 36 & 39.58 \\
\hline
\end{tabular}

the study are immunized their sheep to protect them from infectious diseases. Among lambs, mortality rate of upto $10 \%$ was recorded in $18.27 \%$ flocks, $11-20 \%$ mortality in $41.35 \%$ flocks and more than $20 \%$ lamb mortality in $40.38 \%$ flocks. The higher mortality rate in lambs might be due to post weaning stress, improper adaptability of lambs to feed and fodders and infection during post weaning period. These results are in conclusion with the reports of Singh et al. (2007) who reported a mortality range of $5-20 \%$ in adults and $12-30 \%$ in lambs.

\section{Breeding}

In farmers' flocks, Macherla ewes lambed scatterly round the year as the breeding rams remain always with the ewes during grazing and penned together. Male to female ratio in the field flocks was 1:39.27. The scientific literature suggests an optimum sex ratio of 20-25 ewes per ram in order to prevent the inbreeding and maintain the reproductive health of the breeding ram. Hence, the farmers need to be educated to increase the number of rams in their flocks. Gangaraju (2010) and Anandarao (2010) reported mean ram to ewe sex ratio of $1: 25$ to 44 and 1:43.81, respectively in Vizianagaram sheep.

\section{Socio-economic attributes}

The socio-economic attributes of Macherla sheep are presented in Table 3. The overall mean land holding in the surveyed area was 3.41 acres. Most of the farmers studied were small farmers $(34.78 \%)$ holding 2.5 to 5 acres land followed by $29.34 \%$ land less labor and $22.82 \%$ marginal 
Table 3: Socio-economic attributes of Macherla sheep farmers $(n=92)$

\begin{tabular}{|c|c|c|c|c|}
\hline Sl. No. & Socio-economic attribute & Category & $\mathbf{n}$ & $\%$ \\
\hline \multirow{3}{*}{1} & \multirow{3}{*}{ Family size } & Small (up to 3 members) & 12 & 13.04 \\
\hline & & Medium (4 to 6) & 54 & 58.69 \\
\hline & & Large(above 6) & 26 & 28.26 \\
\hline \multirow{3}{*}{2} & \multirow{3}{*}{ Education } & Primary school & 73 & 79.34 \\
\hline & & Secondary school & 19 & 20.65 \\
\hline & & Degree & Nil & \\
\hline \multirow{2}{*}{3} & \multirow{2}{*}{ Adoption of Sheep husbandry as } & Main occupation & 84 & 89.13 \\
\hline & & Subsidiary occupation & 8 & 8.69 \\
\hline \multirow{5}{*}{4} & \multirow{5}{*}{ Land holding(acres) } & Landless Laborer & 27 & 29.34 \\
\hline & & Marginal Farmers $(0-2.5)$ & 21 & 22.82 \\
\hline & & Small Farmers $(2.5-4)$ & 32 & 34.78 \\
\hline & & Medium Farmers (5-10) & 12 & 13.04 \\
\hline & & Large Farmers (above 10) & Nil & \\
\hline \multirow{2}{*}{5} & \multirow{2}{*}{ Type of land } & Dry & 5 & 5.40 \\
\hline & & Wet & 87 & 94.6 \\
\hline \multirow{2}{*}{6} & \multirow{2}{*}{ No. of farmers cultivated fodder } & Cultivated & 16 & 17.57 \\
\hline & & Not cultivated & 76 & 82.43 \\
\hline \multirow{3}{*}{7} & \multirow{3}{*}{ Source of income } & Agriculture & Nil & \\
\hline & & Sheep Rearing & 64 & 69.56 \\
\hline & & Sheep rearing \& Agriculture & 28 & 30.43 \\
\hline \multirow{3}{*}{8} & \multirow{3}{*}{ Annual Income (₹) } & $75000-100000$ & 56 & 60.86 \\
\hline & & $100000-150000$ & 29 & 31.73 \\
\hline & & $150000-200000$ & 7 & 7.41 \\
\hline \multirow{2}{*}{9} & \multirow{2}{*}{ Management of Animals by } & Own family Members & 83 & 90.2 \\
\hline & & Laborers & 9 & 9.78 \\
\hline
\end{tabular}

$\mathrm{n}=$ number of farmers.

farmers, who have sheep rearing as a main source of livelihood. Similar status were reported from Andhra Pradesh and Karnataka by Choudhary (2013) and Reddy et al. (2018).

The present survey on farmers rearing Macherla sheep revealed that average family size of the farmers was 5.44 members, which concurs well with the findings of Choudhary (2013) in Andhra Pradesh, and Reddy et al. (2018) in Karnataka, while it was lower than the observations of Rajanna (2011) in Andhra Pradesh. Literacy rate plays a key role in adoption of new methods in sheep husbandry. The literacy rate of the selected farmers was found to be $79.34 \%$ with primary and $20.65 \%$ with secondary school education, while Virojirao et al. (2008) and Guruprasad et al. (2019) reported that majority of farmers were either illiterates $(32.67 \%)$ or educated at primary level $(39.33 \%)$ in Chittor district of Andhra Pradesh and Hassan district of Karnataka. The results pertaining to annual income were corroborated well with the reports of Choudhary (2013) and Rajanna (2011) in Andhra Pradesh and Reddy et al. (2018) in Karnataka. On contrary, lower income was reported elsewhere (Rajapandi, 2005; Thilakar and Krishnaraj, 2010; Dhara et al., 2019).

The small land holding size, a good proportion of land less laborers, and ideal climate factors could be the reason for sheep rearing. Many of the sheep farmers (90.2\%) maintained the flocks with their own family members as a source of livelihood. Similar results were reported by Saravana kumar (2003), Gangaraju (2010) and Rajanna (2011).

\section{Morphology}

Morphological features of Macherla sheep were studied from a total of 1279 sheep (61 rams, 692 ewes, and 526 
lambs). The color and other morphological characters of Macherla sheep were distinct from three strains of Nellore sheep (Brown, Jodipi and Palla strains), the only recognized breed of Andhra Pradesh and Vizayangaram sheep a lesser-known sheep breed of North coastal zone of Andhra Pradesh.

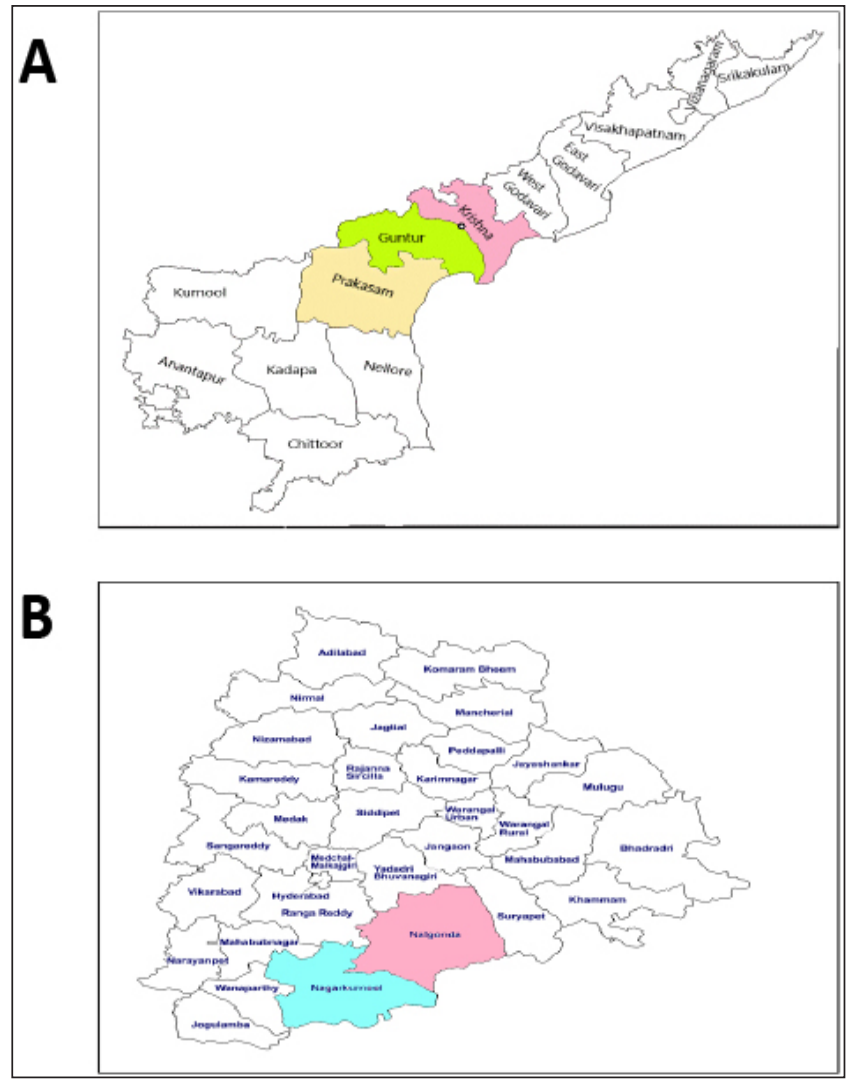

Fig. 1: Areas under study (A) Krishna, Guntur, and Prakasam districts of Andhra Pradesh state and (B) Nalgonda and Nagarkurnool districts of Telangana state

\section{Coat Colour}

Wide variation was observed in the coat colour pattern of Macherla sheep (Fig. 2 and 3). The predominant color pattern observed was bi-colour of white and black (44.41\%), followed by brown and white $(35.65 \%)$, brown $(18.64 \%)$, and black (1.88\%). Majority of sheep had hairy coat $(98.12 \%)$ and very few $(1.88 \%)$ were covered with wooly coat (Fig. 4a). The coat color variant was also observed in Vizayangaram (Gangaraju, 2010) and Vembur (Selvakumar, 2016) sheep breeds earlier.

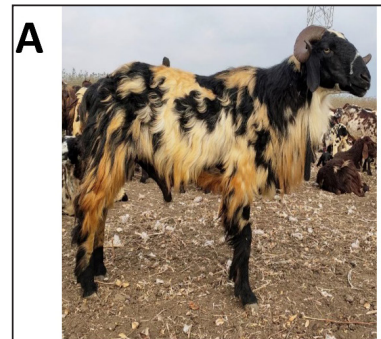

B
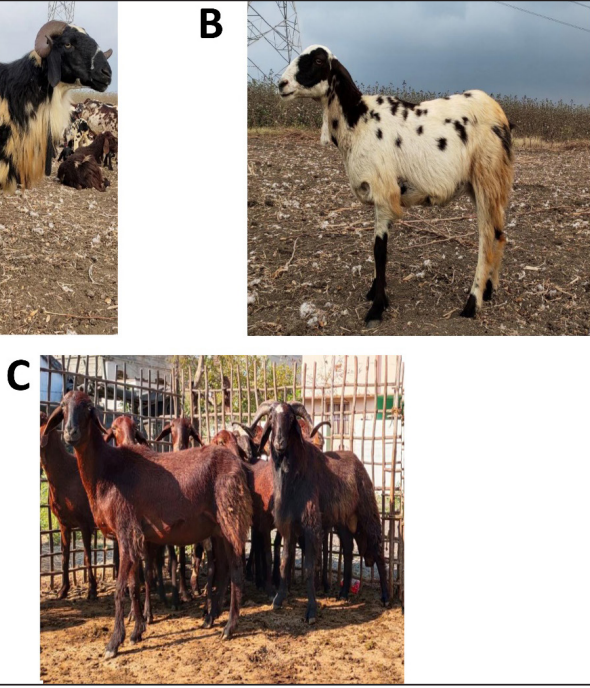

Fig. 2: Colour variants of Macherla sheep (A) Macherla ram with black and white spots; (B) Macherla ewe with black and white spots; and (C) Macherla rams and ewes with brown coat colour

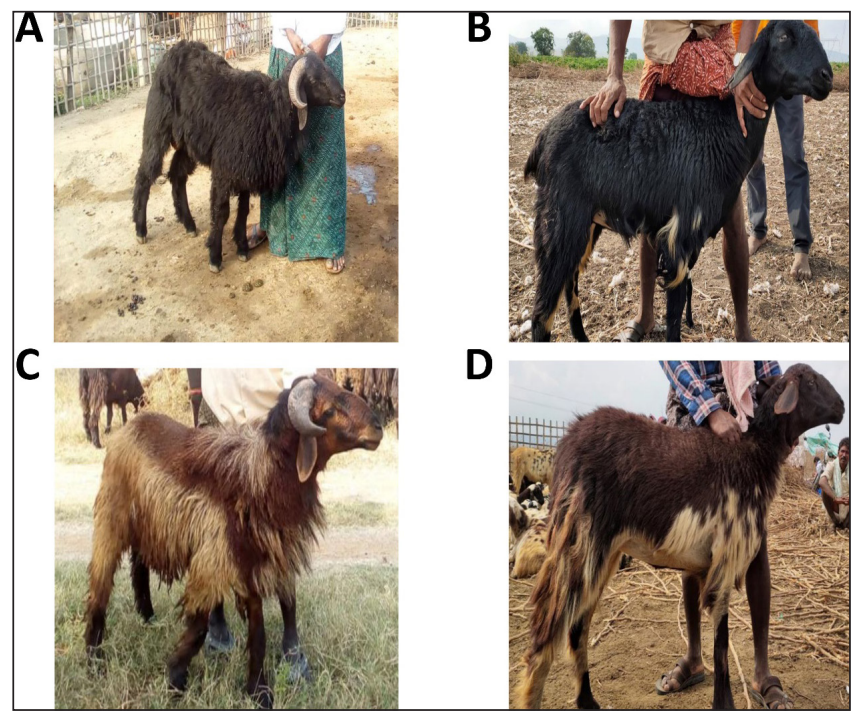

Fig. 3: Colour variants of Macherla sheep (A) Macherla ram with black coat colour (B) Macherla ewe with black coat colour (C) Macherla Ram with brown and white coat color (D) Macherla ewe with brown and white coat color

\section{Head, Ears profiles and Wattles}

The head, ears' profile and wattles of Macherla sheep were peculiar and characteristic (Fig. 4b, c and d). The predominant head profile was convex $(84.91 \%)$, while 
some were with slightly convex heads (12.98\%). The ears pattern was mostly pendulous $(96.79 \%)$. The wattles were present in $75.45 \%$ of Macherla sheep Roman nose or nose similar to Roman (convex) shape was also reported in Nellore (FAO, 1982), Vizianagaram sheep (Gangaraju, 2010), Mandya (Jain et al., 2005), and Macherla sheep (Choudary, 2013). Pendulous ear pattern in sheep was also reported by Choudhary (2013) in Macherla sheep and Yadav et al. (2011) in Munjal breed. Further, few authors reported the presence of wattles in South Indian breeds like Nellore (FAO,1982), Coimbatore (Devendran et al., 2009) and Macherla sheep (Choudhary, 2013). However, Selvakkumar et al. (2016) reported that the wattles were absent in both the sexes of Vembur sheep.

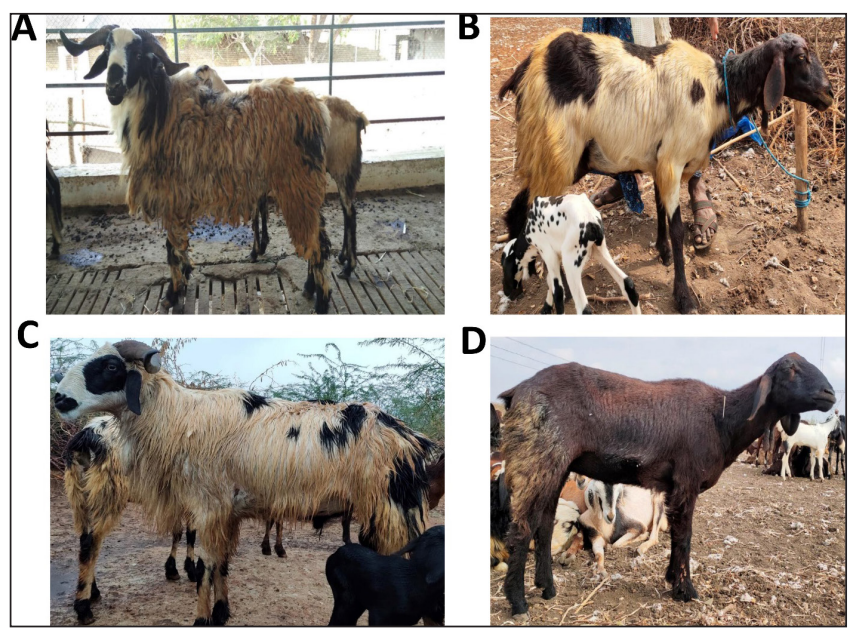

Fig. 4: Head, ears' profile and wattles of Macherla sheep (A) Macherla ram with wooly coat; (B) Macherla Ewe with pendulous ears; (C) Macherla ram with convex head profile; and (D) Macherla Ewe with wattles

\section{Muzzle, eyelids and hooves colour}

The results showed that majority of sheep possessed black colored muzzle $(86.86 \%)$ and some with brown $(11.10 \%)$ and very few with white color $(2.06 \%)$. The eye lid color pattern was mostly brown $(31.50 \%)$, followed by black $(57.54 \%)$ and white $(10.87 \%)$. Majority of the animals had black colored hooves $(99.68 \%)$.

\section{Horn}

Both sexes were horned; but a meagre $2 \%$ of the horned sheep were females. The recorded horns were of two types viz. slightly curved (20.69\%) and curved (79.31\%). In most of the sheep (39.66\%), horns were oriented backward, downward and forward, $21.26 \%$ backward and downward, $16.09 \%$ outward and backward, $4.07 \%$ upward and $18.92 \%$ backward. Horned rams and polled ewes are not unusual in sheep breeds of South India (Anon, 2004).

\section{Tail type, shape and length}

The study revealed that majority of the sheep (84.55\%) had slender type of tail and very few with thin tail $(15.45 \%)$. The tail is curved in most of the flocks $(94.13 \%)$. The tail length in Macherla sheep was classified into short and medium. Overall, $88.04 \%$ animals had short tail and $11.46 \%$ of the animals with medium size tail. These findings were close to the reports published by Choudhary (2013) who reported slender, short tail in majority of the sheep, while the remaining had thin and medium length tail. However, Singh et al. (2007) reported most of the Nali sheep within and medium sized tails.

\section{CONCLUSION}

The study on husbandry practices of the Macherla sheep revealed that the sheep farming in the breeding tract was traditional and adoption of the improved technologies was low. Scientific sheep management practices were generally not practiced by most of the farmers, except adoption of vaccination against few diseases and deworming. Adoption of scientific methods in sheep management and by following suggestion of veterinarians regarding health care would reduce morality percentage in sheep there by increasing the economic status of the shepherds. The variation in coat color among Macherla sheep observed in this study indicates that it has not yet been purified through selective breeding and therefore great opportunities exist for its improvement. The color of the sheep in the tract indicate the need for identifying as a separate genetic group. The combination of white and brown along with white and black coat color and hairy nature suggest the adaptive character of the sheep to tropical and arid climatic conditions.

\section{REFERENCES}

BAHS. 2019. Basic Animal Husbandry and Fisheries Statistics. Department of Animal Husbandry, Dairying \& Fisheries. 
Ministry of Agriculture, Govt. of India. $20^{\text {th }}$ livestock census (2012-2019). Ministry of Agriculture Department of Animal Husbandry, Dairying and Fisheries, Krishi Bhawan, New Delhi-110001.

Chandran, P.C. 1998. Characteristics and performance of Vembur sheep in the habitat. M.V.Sc. Thesis. Tamil Nadu Veterinary and Animal Sciences University, Chennai, India.

Choudhary, P.V. 2013. Characterization of Macherla brown sheep, M.V.Sc thesis submitted to Sri Venkateswara Veterinary University, Tirupati.

Devendran, P., Kandasamy, N., Panneerselvam, S.,. and Thiruvenkadan, A.K. 2010. Rearing environment and husbandry practices of Coimbatore sheep. Indian J. Anim. Sci., 80: 470-472.

Dhara, K.C., Moitra, N.J., Misra, S., Ghosh, S., Bose, S. and Poddar, K. 2019. Socio- Economic Status of the Sheep \& Goat Farmers in Sundarban, West Bengal. Int. J. Livest. Res., 9(9): 167-179.

FAO. 1982. Sheep and Goat breeds of India by Acharya R.M.

Guruprasad, R., rajeshwari, Y.B., Siddeswara, N.C., Kumarn N.S., Rudrappa, S.M. and Sumitra, B.M. 2019. Socioeconomic profile of sheep farmers and flock size of sheep in different agro-climatic zones of Hassan district. Int. J Agric. Sci., 11: 7853-7856.

Hyder, I., Pasumarti, M., Reddy, P.R.K., Prasad, C.S., Kumar, K.A. and Sejian, V. 2017. Thermotolerance in domestic ruminants: A HSP70 Perspective. In: Asea, A., Kaur, P., (eds) Heat shock proteins in veterinary medicine and sciences. Heat shock proteins, vol 12. Springer, Cham; 2017. https:// doi.org/10.1007/978-3-319-73377-7_1

Hyder, I., Reddy, P.R.K., Raju, J., Manjari, P., Prasad, C.S., Kumar, K.A. and Sejian, V. 2017. Alteration in Rumen Functions and Diet Digestibility During Heat Stress in Sheep. In: Sejian, V., Bhatta, R., Gaughan, J., Malik, P., Naqvi, S., Lal, R., (eds) Sheep Production Adapting to Climate Change. Springer, Singapore; 2017. https://doi.org/10.1007/978-98110-4714-5_11

Jain, A., Sadana, D.K., Govindaiah, M.G., Kulkarni, V.S., Aswathnarayan T, Pandey A.K., Kumar D, Sharma R. and Singh, G. 2005. Sheep Genetic Resources of India. Mandya Monograph-2005. National Bureau of Animal Genetic Resources, Karnal, India

Jain, A., Singh, G. and Yadav, D.K. 2009. Chokla - an endangered sheep genetic resource. Indian J. Anim. Sci., 79: 1071-1072.

Kandasamy, N., Pannerselvam, S., Devenran, P. and Thiruvenkadan. 2006. Final report on survey, evaluation and characterization of Coimbatore sheep breed, Department of Animal Genetics and Breeding, VC\&RI, Namakkal.
Kumar, A., Singh, U., Kumar, S., Sharma, R.C. and Arora, A.L. 2008. Malpura: a mutton breed of sheep needs to be conserved. Indian J. Anim. Sci., 78: 740--745.

Kumari, N., Reddy, Y.R., Blummel, M., Nagalakshmi, D., Monika, T., Reddy, V.S.B. and Reddy, R.Ch. 2013. Growth performance and carcass characteristics of growing ram lambs fed sweet sorghum bagasse based complete rations varying in roughage-to-concentrate ratios. Trop. Anim. Health Prod., 45: 649-655.

Mahendran, M. 2009. Phenotypic and Molecular Characterization of Ramnad White Sheep. M.V.Sc. Thesis. Tamil Nadu Veterinary and Animal Sciences University, Chennai.

Mishra, M. and Mohanty, S.C. 1993. Habitat, climate and breed characterization of Ganjam and Bolangir sheep. Indian J. Anim. Prod. Mgmt., 9: 31-34.

Porwal, K., Karim, S.A., Sisodia, S.L. and Singh, V.K. 2006. Socio-economic survey of sheep farmers in western Rajasthan. Ind. J. Small Rumin., 12(1): 74-81.

Rajanna, N. 2011. Socio-economic status and flock management practices of sheep farmers in Telangana region of Andhra Pradesh. 2011. Ph.D. Thesis, Sri Venkateswara Veterinary University, Tirupati.

Rajapandi, S. 2005. Distribution and management practices of Coimbatore sheep. M.V.Sc. Thesis Veterinary College and Research Institute, Namakkal, Tamil Nadu.

Raju, J., Reddy, P., Kumari, N.N., Narasimha, J. and Nagalakshmi, D. 2018. Assessment of potential livestock feed resources in Telangana State, India. Indian J Anim. Res., 52(9): 1285-1291.

Raju, J., Reddy, P., Reddy, A., Kumar, C. and Hyder, I. 2017. Livestock feed resources in surplus rainfall Agro ecological zones of Andhra Pradesh: Requirement, availability and their management. Int. J. Livest. Res., 7(2): 148-163.

Raman, K.S., Sundararaman, M.N., Haribhaskar, S. and Ganesakale, D. 2003. Biometrics and breed characteristics of Madras Red sheep. Indian J. Small Rum., 9: 6-9.

Reddy, B.S., Shivakumara, C. and Dixit, A.K. 2018. Small Ruminant Farming in Karnataka (India): A Pathway of Sustainable livelihood security and enhancing farmer's income. $30^{\text {th }}$ international conference of agricultural economists. Vancover Bolangir sheep. Indian J. Anim. Prod. Manag., 9(1): 31-34.

Reddy, P.R.K, Kumar, D.S., Rao, E.R., Seshiah, C.V., Sateesh, K., Reddy, Y.P.K. and Hyder, I. 2019a. Assessment of ecosustainability vis-à-vis zoo-technical attributes of soybean meal (SBM) replacement with varying levels of coated urea in Nellore sheep (Ovis aries). Plos One, 14: e0220252.

Reddy, P.R.K., Kumar, D.S., Rao, E.R., Seshiah, C.V., Sateesh, K., Rao, K.A., Reddy, Y.P.K. and Hyder, I. 2019 b. 
Environmental sustainability assessment of tropical dairy buffalo farming vis-a-vis sustainable feed replacement strategy. Sci. Rep., 9: 16745.

Saravanakumar, A.K. 2003. A study on the migratory pattern of Nellore sheep and their performance. M.V.Sc., Thesis submitted to Acharya N.G. Ranga Agricultural University, Hyderabad, Andhra Pradesh.

Selvakkumar, R., Sivakumar, T., Meenakshi Sundaram, S., Jawahar, K.T.P and Vanan, T.T. 2016. Phenotypic characterization of Vembur sheep in its breeding tract. Indian Vet. Jour., 93(11): 36-38.

Singh, G., Jain, A., . and Yadav, D.K. 2007. Evaluation of Nali sheep under field conditions. Indian J. Anim. Sci., 77(11): 1158-1160.

Snedecor, G.W. and Cochran, W.G. 1989. Statistical Methods. $\left(8^{\text {th }}\right.$ edn. $)$ Iowa state University Press, Ames, Lowa, pp. $\mathrm{xx}+503$.

Sushilkumar, R., Sharma, C., Mishra, A.K. and Arora, A.L. 2003. Production performance of sheep and certain management practices in farmers flocks of southeast Rajasthan. Indian $J$. Small Ruinm., 9(2): 103-105.
Thilakar, P. and Krishnaraj, R. 2010. Profile characteristics of sheep farmers-a survey in Kanchepuram district of Tamil Nadu. Indian J. Field Vet., 5: 35-36.

Thiruvenkadan, A.K., Karunanithi, K. and Purushothaman, M.R. 2004. Socio-economic status of the Mecheri sheep farmers and economics of rearing under farmers management system. Indian J. Small. Rumin., 10: 1-6.

Thiruvenkadan, A.K., Purushothaman, M.R., Karunanithi, K. and Singh, G. 2007. Husbandry practices for Mecheri sheep in its breeding tract of Tamil Nadu. Indian J. Anim. Sci. 77: 489-493.

Viroji Rao, S.T., Tammiraju, D. and Ravindra Reddy, Y. 2008. Adoption of sheep husbandry practices in Andra Pradesh, India. Livestock Res. Rural Deve., 20(7).

Yadav, D.K., Arora, R., Bhatia, S. and Singh, G. 2011. Morphological characterization, production and reproduction status of Munjal - a threatened sheep population of NorthWest India. Indian J. Anim. Sci., 81: 943-945. 
